IZA DP No. 5253

Her Time, His Time, or the Maid's Time:

An Analysis of the Demand for Domestic Work

Elena G. F. Stancanelli

Leslie S. Stratton

October 2010 


\title{
Her Time, His Time, or the Maid's Time: An Analysis of the Demand for Domestic Work
}

\author{
Elena G. F. Stancanelli \\ CNRS, THEMA, University Cergy Pontoise \\ Leslie S. Stratton \\ Virginia Commonwealth University \\ and IZA
}
Discussion Paper No. 5253
October 2010

\author{
IZA \\ P.O. Box 7240 \\ 53072 Bonn \\ Germany \\ Phone: +49-228-3894-0 \\ Fax: +49-228-3894-180 \\ E-mail: iza@iza.org
}

Any opinions expressed here are those of the author(s) and not those of IZA. Research published in this series may include views on policy, but the institute itself takes no institutional policy positions.

The Institute for the Study of Labor (IZA) in Bonn is a local and virtual international research center and a place of communication between science, politics and business. IZA is an independent nonprofit organization supported by Deutsche Post Foundation. The center is associated with the University of Bonn and offers a stimulating research environment through its international network, workshops and conferences, data service, project support, research visits and doctoral program. IZA engages in (i) original and internationally competitive research in all fields of labor economics, (ii) development of policy concepts, and (iii) dissemination of research results and concepts to the interested public.

IZA Discussion Papers often represent preliminary work and are circulated to encourage discussion. Citation of such a paper should account for its provisional character. A revised version may be available directly from the author. 
IZA Discussion Paper No. 5253

October 2010

\section{ABSTRACT \\ Her Time, His Time, or the Maid's Time: An Analysis of the Demand for Domestic Work ${ }^{*}$}

This paper analyzes households' demand for time inputs to domestic services, modeling simultaneously the decision to purchase services in the market and the time spent on weekend and weekday days by each partner on routine household chores. By focusing on cleaning, laundry, and ironing, we reduce the likelihood that preferences matter and increase the overlap with market services. Particular emphasis is placed on estimating the effects of prices, as captured by own and partner wages and the market price for domestic services. We exploit time-diary data for Great Britain and France, relying on cross-country comparisons to generalize our findings. The results indicate that prices strongly influence market purchases, and that maid service is a closer substitute for household time on weekends than weekdays, but is also correlated with 'her' weekday time. More generally, we find that women's wages have a stronger association with the inputs to domestic work than any other price measure.

JEL Classification: J22, J16

Keywords: $\quad$ time use, domestic work, gender

Corresponding author:

Leslie S. Stratton

Department of Economics

Virginia Commonwealth University

301 W. Main Street

Richmond, VA 23284-4000

USA

E-mail: Isstratt@vcu.edu

*We thank Robert Pollak and participants to the 2010 IATUR conference in Paris for helpful comments. All errors are ours. 


\section{Her time, his time, or the maid's time: An analysis of the demand for domestic work}

A substantial fraction of what we consume is produced in the home - prepared food, clean clothes, and clean living space. Yet relatively little is known about how these goods are produced. The scant literature on these home production activities focuses either on the domestic help industry or on the time spent or specialization demonstrated within couple households. Here, we draw from both these literatures to simultaneously analyze household demand for domestic help and the time partners spend on routine household chores.

We exploit time-diary data for Great Britain and France that include supplemental information on domestic services purchased from the market to estimate simultaneously all time inputs to the household production of domestic chores. The focus here is on time spent in the home rather than in the yard, and on chores not child care. Only a small minority of households buy domestic services (approximately 7\% in each country). We argue that this decision reflects either that individuals derive pleasure from the time spent in these activities, or that the market price for domestic services is too high relative to the household reservation price, or that market services are an imperfect substitute for home production. However, preferences do not appear to explain why couples hire maids so infrequently. Our data indicate that very few individuals enjoy routine housework chores. We investigate whether prices, as captured by own and partner wages and the market price of domestic services, influence the decision to purchase domestic help as well as the time allocated by each partner to domestic chores. We conclude that the woman's wage has a strong impact on all time inputs in both countries. By examining crossprice elasticities and correlations among the residuals, we are also able to investigate the degree 
to which the various inputs to home production are substitutes for one another, both in general and on weekends and weekdays separately. We find evidence that the higher her value of time, the more domestic help is purchased, the more time he spends on housework, and the less time she spends on housework. We also find evidence that the maid's time is a closer substitute for weekend rather than weekday housework time, but also associated with 'her' weekday time. The results are remarkably robust between countries, suggesting that our findings may be more generalizable than would be indicated by a single country study.

\section{The Literature}

Data drawn from the American Time Use Survey show that on average Americans currently spend more than 20 hours per week working for their own household without pay on tasks that might be done by a paid worker, and women on average spend more time at such unpaid household work than do men (Krantz-Kent, 2009). The contribution housework would make to national GDP if it were to be included in national accounts is substantial. Estimates range from 24\% of total 1997 GDP (housework included) in the US (Landefeld and McCulla, 2000) to between 27 and 39\% of GDP (depending on how it is valued) the same year in Switzerland (Sousa-Poza, Schmid, and Widmer, 2001). Estimates of a similar magnitude are obtained using time diary data for Australia, Bulgaria, Denmark, Finland, France, Germany, and Norway (Goldschmidt-Clermont and Pagnossin-Aligisakis, 1999). Though still noteworthy, there is substantial evidence that the home production sector has shrunk. The number of overall hours of domestic labor (including childcare and shopping) has declined steadily since 1965 (Bianchi et al., 2000). 
Analysis of the home production sector has primarily focused on the effect of individual earnings on the amount of housework performed by each partner in couple households (see Bonke et al., 2008, for a review of the literature and a comparison of the United States and Denmark). To give some examples, Gupta and Ash (2008) argue that the level of own earnings is a significant determinant of the amount of housework performed, especially for women, more so even than the share of own earnings in total household income. Using data drawn from the American Time Use Survey, Connelly and Kimmel (2009) find that relative earnings and other spousal characteristics have very little effect on the level of the other spouse's unpaid time use. However, Bloemen and Stancanelli (2008) using the French Time Use Survey, find that own and spousal earnings significantly affect time allocation choices. In particular, the amount of housework provided by men is found to increase significantly the higher the wage of their wife.

In contrast to the large literature on the time allocated to domestic chores, the literature on the demand for domestic services and the domestic help industry is limited. Wing (1994) reports that women's wages are significantly positively related to the probability of hiring domestic servants in Hong Kong, concluding that domestic servants and a woman's own time are substitutes in the household production process. Cohen (1998) finds similar results in the US, but also reports a weaker positive relation with 'his' earnings. Focusing also on attitudes towards hiring domestic services, Baxter et al (2009) determine that they matter as much as financial resources in the hiring of domestic services in Australia. Cortes and Pan (2009) estimate the effect of the supply of foreign domestic helpers on female labor supply in Hong Kong and find that changes in immigration law easing the recruitment of foreign domestic workers have led to a significant increase in female labor supply. In a more standard demand model, Flipo, Fougere, and Olier (2007) investigate the effect of tax reductions on the demand 
for domestic workers in France in the late nineties, concluding that only rich households have benefited from this policy. They find, using data drawn from a special INSEE survey on the issue, that only about 6 per cent of French households hired domestic help in 1996 and less than half of those households were benefiting from the tax reductions. Surveys about the use of domestic services in France indicate that the majority of respondents would like to hire domestic services from the market but do not do so mainly because of income (budgetary) constraints (Flipo, 1996).

We are not aware of any earlier study that has looked at the decision to purchase domestic services from the market in conjunction with the home production of such services, defined to include cleaning, ironing, washing, and the like, as we do here. In somewhat related work, Hamermesh (2007) has studied the household production function for "eating". Using time diary data from 1985 and 2003 in the United States, Hamermesh estimates linear input demand equations, specifying as inputs the raw food materials that make up meals and also the time devoted to buying food, preparing meals and eating them, and cleaning up afterwards. The key explanatory variables are income and the husband's and wife's value of time. He concludes that income has a positive effect on purchased inputs and that the opportunity cost of time is negatively related to the time devoted to the production of eating, notwithstanding that there is little scope for substitution between the purchased and home-produced inputs. Aguiar and Hurst (2005) also investigate the production of "eating". They find that following retirement, the reduction in food expenditure (known as a retirement consumption puzzle) is matched by an increase in the time spent shopping and preparing meals, such that overall there is no decline in food intake. By contrast, they find that the unemployed do experience such a decline. These 
studies of household food production illustrate the importance of taking both market and household inputs into account in modeling the economically significant home production sector.

\section{The theoretical framework}

As customary, we assume that the household welfare function is a function of each partner's utility: $\mathrm{W}_{\mathrm{h}}=\mathrm{W}\left(\mathrm{U}_{\mathrm{m}}, \mathrm{U}_{\mathrm{f}}\right)$, where $\mathrm{U}_{\mathrm{m}}$ and $\mathrm{U}_{\mathrm{f}}$ stand, respectively, for his and her utility. Each individual's utility function includes as arguments that individual's leisure time (1), that individual's goods consumption (C), and a household public good $\mathrm{C}_{\mathrm{h}}$ that reflects domestic services: $U_{k}=U_{k}\left(l_{k}, C_{k}, C_{h}\right)$ where $k=m$ or $f$. We specify the household production function for domestic services - the public good in this set up - as $C_{h}=V\left(h_{m}, h_{f}, d\right)$, where $h_{m}$ and $h_{f}$ represent the time he and she spend on domestic chores and d represents time purchased in the market at price $\mathrm{p}_{\mathrm{d}}$ for domestic chores. The household welfare function is maximized subject to time constraints for each partner - that the sum of all time uses cannot exceed 24 hours a day $\left(l_{i}+\right.$ $\left.\mathrm{h}_{\mathrm{i}}+\mathrm{t}_{\mathrm{i}} \leq 24\right)$ - and the household's 'full-income' budget constraint:

$$
\mathrm{C}_{\mathrm{m}}+\mathrm{C}_{\mathrm{f}}+\mathrm{p}_{\mathrm{d}}^{\prime} \mathrm{d}+\mathrm{w}_{\mathrm{m}}\left(\mathrm{h}_{\mathrm{m}}+\mathrm{l}_{\mathrm{m}}\right)+\mathrm{w}_{\mathrm{f}}\left(\mathrm{h}_{\mathrm{f}}+\mathrm{l}_{\mathrm{f}}\right)=24\left(\mathrm{w}_{\mathrm{m}}+\mathrm{w}_{\mathrm{f}}\right)+\mu
$$

where the cost of goods (C) is normalized to one, the market wage is denoted $w, t_{i}$ denotes market work, and $\mu$ denotes non-labor income.

Theoretically one can with sufficient assumptions solve this utility maximization problem to generate precise structural demand equations for each input: leisure, goods, and housework time. However, there are numerous problems with such a structural approach. First, to derive such a structural model it is necessary to specify how the utility functions of the partners are combined to form the household welfare function. This can be accomplished by specifying a weighting function or a bargaining model, but different assumptions will yield different 
specifications. ${ }^{1}$ Second, it is necessary to measure the household public good either in terms of quantity or value. We observe neither. ${ }^{2}$ Third, ideally we would know individual (marginal) productivity in household production, but while market wages are observed, individual (marginal) productivity in household production is not. ${ }^{3}$ In general, the derivation of precise structural demand equations requires specific, often restrictive, assumptions about the behavior and production techniques of households.

Thus we adopt a reduced form specification - like, for example, Hamermesh (2006) for eating inputs or Aguiar and Hurst (2005) - modeling the time inputs to domestic work: $\mathrm{d}, \mathrm{h}_{\mathrm{f}}$, and $\mathrm{h}_{\mathrm{m}}$. The underlying utility framework is important for understanding the parameter estimates. All else equal, any individual's time on housework will be higher, the greater the utility the household derives from the public good, the lower the opportunity cost of that individual's time, and the higher the opportunity cost of obtaining equivalent services from the partner or the market. The welfare maximizing level of $\mathrm{C}_{\mathrm{h}}$ will be determined both by perceived household needs or demand (likely driven in large part by the size and composition of the household) and by the manner in which the individual partners' utility functions are combined to form the household utility function. If, as is typical in the collective model, the weights assigned to each partner indicate each individual's economic 'power', then $C_{h}$ will be higher the more important home production is to the more powerful partner (see Pollak, 2005). Likewise it is important to recognize the household production function V (see Pollak, 2010, for a thorough discussion of household technologies). Time inputs by different partners and from the market may not be

\footnotetext{
${ }^{1}$ In addition, we do not observe any variables, such as the non-labor income of each spouse, that would enable us to estimate these weights.

${ }^{2}$ We do not observe how much is cleaned or how well, what meal is prepared or how much that meal is enjoyed, or how much the household values the public good.

${ }^{3}$ The amount and quality of the meal depends not only on the amount and quality of the ingredients but also on the skills of the cook, which are not necessarily related to market wages.
} 
directly comparable and characteristics likely to lead to differences in productivity need to be incorporated in the specification. Finally, there may be some substitutability between each partner's time, and between each partner and any time purchased on the market towards production of the public good.

The structural model leads to demand functions for the optimal time each partner will devote to domestic chores (h) and the optimal domestic help that the household purchases from the market (d) that will have the following general form where $\mathrm{z}$ represents other covariates:

$$
\begin{aligned}
& \mathrm{h}^{*}{ }_{\mathrm{k}}=\mathrm{h}_{\mathrm{k}}\left(\mathrm{w}_{\mathrm{m}}, \mathrm{w}_{\mathrm{f}}, \mathrm{p}_{\mathrm{d}}, \mu, \mathrm{z}\right), \mathrm{k}=\mathrm{m}, \mathrm{f} \\
& \mathrm{d}^{*}=\mathrm{h}_{\mathrm{s}}\left(\mathrm{w}_{\mathrm{m}}, \mathrm{w}_{\mathrm{f}}, \mathrm{p}_{\mathrm{d}}, \mu, \mathrm{z}\right)
\end{aligned}
$$

The expected impact of wages on the time allocated to domestic chores is difficult to sign a priori. Consider, for instance, an increase in her wage rate, $\mathrm{w}_{\mathrm{f}}$, all else constant. An increase in $\mathrm{W}_{\mathrm{f}}$ means that the price of her time has increased relative to (i) the price of the time of her husband and (ii) the price of market alternatives for household production. This would suggest that she should spend less time in household production while he spends more time and they purchase more help in the market. Consumption of the household public good $\mathrm{C}_{\mathrm{h}}$ is also likely to fall given its now higher cost, further supporting a decline in $\mathrm{h}_{\mathrm{f}}$. How sensitive her domestic time $\left(\mathrm{h}_{\mathrm{f}}\right)$ will be to her wage depends upon her relative productivity at home production; the degree to which $\mathrm{h}_{\mathrm{f}}, \mathrm{h}_{\mathrm{m}}$, and $\mathrm{d}$ are substitutes for one another in home production; and household preferences for the public good. It is of some interest to note that an increase in $\mathrm{w}_{\mathrm{f}}$ may also affect $h_{f}$ through its impact on her negotiating power within the household. If she values household production, $\mathrm{C}_{\mathrm{h}}$, more than he does, then when her bargaining power increases she may negotiate for a higher level of production of $C_{h}$. An increase in $C_{h}$ will require more inputs and 
so may require she spend more time in domestic pursuits. Thus, in fact, not only the magnitude but also the direction of the effect a change in $\mathrm{w}_{\mathrm{f}}$ has upon $\mathrm{h}_{\mathrm{f}}$ is an empirical question.

As regards the price of domestic help purchased from the market, we expect a higher $\mathrm{p}_{\mathrm{d}}$ to lead to a reduction in its quantity demanded, $\mathrm{d}$, and a reduction in the total amount of the household public good, $\mathrm{C}_{\mathrm{h}}$. The reduction in $\mathrm{C}_{\mathrm{h}}$, however, is likely to be smaller than that caused by the reduction in $\mathrm{d}$ because of the possibility of substituting household labor for market labor. Thus, the amount of domestic work produced by each partner is likely to rise to partially offset the reduction in $\mathrm{d}$. How much $\mathrm{h}_{\mathrm{f}}$ and $\mathrm{h}_{\mathrm{m}}$ rise will be determined by how close a substitute each partner's household labor is for the market purchased service.

The implications are similar considering this problem from a different perspective. Holding demand for domestic work constant, one partner may perform more housework the lower his/her opportunity cost of time, the more expensive the alternatives (his/her partner's opportunity cost of time and the cost of purchased care), and the poorer the substitutes.

Finally, the scope for substitution of partners' time inputs and maid's time may vary over different week days as a result of variation in either individual time budgets or household needs. Employed individuals tend to be less time constrained on weekends and thus more available to perform housework. On the other hand, some domestic tasks may need to be performed every day - like setting and unsetting the table, doing the dishes, and meal preparation - while others may be scheduled less frequently - like laundry and ironing. Some tasks may be better suited for market provision as well. Our data allow us to identify what day of the week housework time is reported so that we can control for some of these differences. Furthermore, we experiment with two different definitions of housework. Given the fixed costs associated with maid service, it is unlikely that a maid would be hired to come in to set and clear a table. 
Finally, our specification will allow us to estimate the degree to which unobservable factors affecting the demand for different time inputs in the household production of domestic services are correlated. Estimating these cross-equation correlation terms will improve the efficiency of our parameter estimates. The estimates themselves may also be indicative of the degree of substitutability between these different time inputs. Significant negative correlations between purchased services and household services may be indicative that these inputs are substitutes in the home production function.

\section{The data}

\subsection{Analysis Sample Criteria}

The data for this analysis are drawn from two countries, France and Great Britain. The primary source of the French data is the 1998-99 French time-use survey (Enquete Emploi du temps, henceforth EDT), carried out by the National Statistical Office (INSEE). This is the latest time use survey available for France to date. The primary source of the British data is the 20002001 United Kingdom Time Use Survey (UKTUS). The EDT samples 8187 representative households and includes over 20,000 individuals of all ages. The UKTUS samples 6414 households and includes over 10,000 individuals of all ages.

Each of these surveys collected three types of questionnaires: household questionnaires with such household-specific information as household composition and location; individual questionnaires with such individual-specific information as age, education, and employment; and individual-specific 24-hour time diaries. For the time diaries, individuals were asked to use their own words to complete a written diary of their activities for each of 144 ten minute intervals. These activities were then recoded into approximately 140 standardized activities. One 
advantage of both these surveys is that time diaries were collected for each adult in the household and for the most part all household members filled out diaries for the same day. In the case of the French data, diaries were collected for only one day - either a weekday or a weekend day. In the case of the British data, diaries were collected for both a weekday and a weekend day.

Both samples are restricted to heterosexual couple households. The British sample is further restricted to exclude those households residing in Northern Ireland as local labor market information that we use to predict earnings is not available for this subsample and those households that do not complete the individual level surveys. These restrictions yield samples of 5287 households in France and 2893 households in the UK. Using individual information, we restrict the sample to couples between the ages of 20 and 59 inclusive in which neither partner reports being enrolled in school full-time, in the military, or retired. This yields samples of 3405 households in France and 1782 in the UK. Finally the sample is restricted to households that provide information on purchased services, households for whom sufficient information is available to impute prices, and households for which both partners complete at least 23 hours and report at least five different activity spells for each possible time diary on days that are not deemed 'unusual'. ${ }^{4}$ Our goal is to obtain reliable diary information for a normal day. ${ }^{5}$ Our final sample consists of 2924 households in France and 1290 households in the UK.

\footnotetext{
${ }^{4}$ An 'exceptional day' in France is defined to include vacation days, special holidays, special occasions (like weddings or funerals), sick days, and the like. Similar information is not available for the UKTUS, however we were able to exclude holidays and days during which the respondent was likely sick - as judged by reporting more than 30 minutes in bed sick or twenty or more hours sick or sleeping.

${ }^{5}$ Juster (1985) finds that diaries that include very few distinct activities are unreliable.
} 


\subsection{Housework Time}

Identifying what constitutes housework time is of critical importance for this analysis.

First we focus on activities that are of a routine sort of nature as might be performed in any household. Housework activities that some equate with hobbies such as baking, handicraft, woodworking, home repair, gardening, and pet care are excluded in order to minimize the chance that individuals derive direct utility from the activity - thus leaving less scope for substitution with market services for domestic work. Child-care is excluded both because many parents enjoy this activity and because there is evidence that the determinants of child care and housework are quite different (Kimmel and Connelly, 2007). These exclusions leave a definition of housework that includes food preparation and cleanup, general cleaning, laundry, ironing, shopping $^{6}$, and services (including banking) - and corresponds to what is usually defined as "routine" or "compulsory" housework.

However, it is obviously still possible that individuals may derive pleasure from some of these activities. To explore that possibility, we examine preference data on housework tasks that are available in both surveys. A substantial fraction of individuals fail to provide information on preferences either because they do not answer the questions (UK only) or because they report not engaging in the activity. ${ }^{7}$ Figure 1 summarizes the available preference data by country, gender, and activity type. Panel A presents the results for Great Britain and Panel B the results for

\footnotetext{
${ }^{6}$ For shopping, the French questionnaire does not distinguish shopping for food and shopping for other goods while the UK questionnaire does.

${ }^{7}$ About $13 \%$ of the men and $3 \%$ of the women in the British sample did not answer the questions. In both countries, information on preferences was only collected from individuals who reported performing the activity. The fraction of individuals reporting not engaging in an activity varied considerably by activity, gender, and country. Less than $3 \%$ of women in France or the UK reported not preparing a meal, not food shopping, or not cleaning the house. This compares with about $10 \%$ of men in the UK and up to $63 \%$ of men in France (for cleaning). Controlling for preferences is not feasible with so many not reporting. For ease of exposition, we suppress information on those persons not reporting preferences in the descriptive statistics presented.
} 
France. The fraction that enjoys an activity in France or enjoys it very much in Great Britain is illustrated in white while the fraction that is indifferent to an activity is illustrated in grey and the fraction that dislikes an activity is illustrated in black. Those who enjoy an activity a little in Great Britain are captured in light grey. For both countries we have information on preferences pertaining to cooking everyday meals, shopping for food, cleaning, ironing, cooking for special occasions, gardening, and home repair. For France we also have information on preferences for dish washing. For Great Britain we have information for laundry and shopping for non-food items.

The results indicate that substantially fewer people derive much pleasure from cleaning, laundry, or ironing as compared to cooking for special occasions, gardening, and home repair. Less than $40 \%$ of British men and less than $50 \%$ of British women report any enjoyment from the former tasks whereas between 60 and $80 \%$ report enjoying the latter. This distinction is even clearer from the French data in which case less than $20 \%$ report enjoying the former and over $70 \%$ report enjoying the latter. Preferences for everyday cooking suggest that British individuals rather enjoy it. While it would be difficult to say that French men and women enjoy everyday cooking, they are more than twice as likely to say they enjoy it as they are to say that they enjoy cleaning, laundry, or ironing. Neither the British nor the French report enjoying food shopping, but Figure 1 shows that British women enjoy 'other shopping'.

This information on preferences provides further support for our decision to exclude gardening and home repair, but also suggests that including food preparation and shopping may complicate our demand analysis as these activities may constitute not just productive activities, 
but direct utility-generating activities. Thus, in the analysis that follows, we focus on a narrower definition of housework that focuses on cleaning, laundry, and ironing. ${ }^{8}$

The distribution of time spent on housework, according to our preferred definition, is portrayed in Figure 2 separately by country, gender, and weekday/weekend day. These panels clearly indicate that women spend more time on housework than men and that more time is spent on housework on weekends than on weekdays. Neither of these results is surprising. The results also indicate that more French men report no time on housework than British men and that (likely to compensate) French women are more likely to report positive time and more of it.

\subsection{The Maid's Time}

Both surveys contain as well a measure of the time each household purchases in the market for housework services. The French questionnaire asks whether the household regularly purchases domestic help/services and if so how much time is purchased each week. ${ }^{9}$ The British questionnaire asks separately about paid help for "cleaning, tidying up" and "ironing" over the last four weeks. There are then additional questions about who provides the help ${ }^{10}$, how often, and for how long. In the case of both surveys, we recoded responses to construct a measure of average time purchased per day.

Table 1 provides summary statistics on purchased services in the UK and France. The most notable fact is that relatively few households purchase any services, in each case less than 10\%. Most of the rest purchase less than 60 minutes a day.

\footnotetext{
8 This definition is further supported by an examination of the British data on paid work. The British survey distinguishes between paid work for "food preparation", "cleaning, tidying up", "ironing", "shopping or errands", and "household accounts". The vast majority of purchased aid is for cleaning/tidying up activities, with ironing the second most common. None of the other activities is purchased by even $1 \%$ of the sample.

${ }_{9}$ This does not include childcare services (which is asked in a separate set of questions). It includes only domestic tasks (taches menageres, in French).

${ }^{10}$ We ignore paid help from family members.
} 


\subsection{Prices}

In the reduced form specification that follows, the variables of greatest interest from an economic perspective are the prices of each party's time. Thus information is needed on the market price of maid service and the opportunity cost of time for both partners.

The median price of domestic services is estimated for France using the French Labour Force Survey 1998, which contains wages of workers in this specific industry, as well as information on regional variation. ${ }^{11}$ These wages are gross of income taxes but net of social security contributions. The British data on domestic service prices are obtained from the British Annual Survey of Hours and Earnings as conducted by the Office of National Statistics. These data provide annual information by region on median gross hourly pay for elementary occupations in sales and service, a category that includes "cleaners, domestics". ${ }^{12}$ In the case of both the French and the British data, we use the natural log of the regional median hourly pay for domestic services as our price of maid service.

To construct measures of individual opportunity cost we employ imputed log wages. Log wages are imputed separately by gender by means of a sample selection controlled log wage specification. To this end, the sample off which wages are calculated is not restricted by availability of time diary data or by marital/cohabitation status. In the case of the UK, residents

\footnotetext{
${ }^{11}$ Different measures of the wages of domestic industry workers were explored, combining answers to different questions on industrial classification and the type of job performed, but they did not lead to substantially different results. We also tried to account for the degree of urbanization to estimate the median price per region, but this variable was never significant. Finally, we experimented with estimates of the number of foreign persons with primary or lower education to proxy for the supply of domestic workers - and thus instrument for the price of domestic workers - but this variable did not perform well in the empirical model.

${ }^{12}$ Results using the pay of "domestic staff and related occupations" were substantially similar. Alternative measures obtained for "cleaners, domestics" from the British Labour Force Survey were explored, but the sample size for these values was very low and the variance quite high.
} 
in Northern Ireland are still excluded as are individuals missing own or partner information on education or age or household information on non-labor income receipt.

A total of 2571 (4141) men and 3015 (4560) women are included in the British (French) wage analysis, including individuals not in employment. The measures of earnings are net of income taxes and contributions for the UK sample; and gross of income taxes but net of social security contributions for the French data. Hourly wages are calculated by dividing monthly earnings by usual monthly hours. Upper and lower cutoffs are imposed on the hourly pay measures to exclude approximately $1 \%$ of the samples. Characteristics of the household and the partner as well as season and computer ownership are used to identify the selection equations from the wage regressions. The wage equations were then used to predict unconditional wages for each partner. Details of these wage imputations are available upon request from the authors. These estimated wage measures constitute estimates of each individual's value/cost of time and as such we enter them among the regressors of the demand equations. As estimates, they introduce error. We bootstrap the standard errors of the econometric model in order to obtain more robust standard errors.

\subsection{Other Explanatory Variables}

In addition to the price variables, we include other measures to control for crosshousehold differences in demand for household production, taste for household production, and ability to pay. Neither data set contains detailed information on non-labor income, an important variable that may impact ability to pay for outside services. For the French data, we construct a dummy variable to identify households that receive rents or dividends. For the UK, our nonlabor income dummy identifies households receiving rents, dividends, or alimony. Dummy variables are also incorporated to identify those living in London or Paris. Numerous factors 
may differ in these major cities, for example cultural attitudes that influence preferences for domestic work. A dummy variable to identify the summer season is incorporated in recognition that the housework tasks performed may differ by season, particularly during the summer.

Controls for various household characteristics are also included. One such is a dummy variable to distinguish between married and cohabiting households. Cohabiters may be more independent and invest less in household production since their long run opportunity to recoup such investments is more limited. Information on the presence of children of various ages is included primarily with the intent of controlling for differences in demand. The presence of other household adults also suggests a greater need for services. Of course, older children and other adults could also help provide household labor, thus their impact is not clear ex-ante.

Dummy variables identifying nonwhite persons in the UK and persons not born in France (minorities, in our model) are incorporated in recognition that there may be cultural differences in the valuation of home production. Individuals who state that they are in bad or very bad health are flagged. Such individuals may be less able to complete housework or may take longer to do so. Individuals who have a college degree or more are identified as there exists some evidence that more educated men are more willing to do housework and that more educated women may be more likely to "do gender" (see, for example, Bianchi et al., 2000, for a discussion). Information on the age of each partner is included as this may also capture attitudes towards domestic work.

Sample statistics for all the explanatory variables are provided in Table 2. 


\section{The empirical model}

Our goal is to estimate the impact prices have on time spent on housework by each individual and on domestic services purchased in the market. We model $\mathrm{h}_{\mathrm{ijk}}$, the time (in hours) spent on domestic work by household member $k(k=m, f)$ of household $i(i=1, \ldots, N)$ on day $j$ (weekend, weekday) using OLS. ${ }^{13}$ We specify linear-log demand equations where the dependent variable is time allocated to housework and the prices are entered in log form (the imputed wage rates of the husband and wife are $\mathrm{w}_{\mathrm{im}}$ and $\mathrm{w}_{\mathrm{if}}$ and the price of domestic services purchased from the market is $\mathrm{p}_{\mathrm{d}}$ ). As described above, we also allow the demand to be affected by other household and individual characteristics $\mathrm{z}$, and an error term $\mathrm{u}$ :

$$
\mathrm{h}_{\mathrm{ijk}}=\gamma_{\mathrm{m}} \ln \mathrm{w}_{\mathrm{im}}+\gamma_{\mathrm{f}} \ln \mathrm{w}_{\mathrm{if}}+\theta \ln \mathrm{p}_{\mathrm{di}}+\mathrm{z}_{\mathrm{ik}}{ }^{\prime} \lambda+\mathrm{u}_{\mathrm{ijk}}
$$

Given the small number of households that purchase domestic-help services, we model the probability of purchasing domestic services rather than its intensity using a Probit specification. ${ }^{14}$ Let $d_{i}$ denote the continuous measure of domestic work purchased by household $\mathrm{i}(\mathrm{i}=1, \ldots, \mathrm{N})$. Then the Probit specification is executed using $\mathrm{d}_{\mathrm{i}} *=1$ if $\mathrm{d}_{\mathrm{i}}>0$, else 0 . Purchased domestic time is modeled as a function of the same variables as housework time provided by the husband or wife:

$$
\begin{aligned}
& d_{i}=\psi_{m} \ln w_{i m}+\psi_{f} \ln w_{i f}+\xi \ln p_{d i}+z_{i k}{ }^{\prime} \pi+v_{i} \\
& d^{*}{ }_{i}=1 \text { if } d_{i}>0 \\
& d^{*}{ }_{i}=0 \text { otherwise }
\end{aligned}
$$

\footnotetext{
${ }^{13}$ Using OLS implies that the zero records for house work may capture infrequencies (ie. not having performed the task on the day the diary was collected), rather than choice of never performing the activity which would be the presumption of a tobit specification (Stewart 2009).

${ }^{14}$ As a sensitivity check, we also estimate domestic-help using a Tobit specification, obtaining similar results.
} 
As all the price measures are in log form, the coefficient estimates in the household time equations are interpretable as the impact a one percent change in price has on time. We report both coefficient estimates and marginal effects in the case of the purchased time Probit specification.

Using the recursive approach in Roodman (2007 and 2009), we estimate equations (3) and (4) simultaneously and identify the correlations between these equations. The system consists of four equations for housework, one equation for each partner on a weekend day and one for each on a weekday day, and an equation for the probability of purchasing domestic services from the market: a total of five equations. As each partner provides information on both a week- and a weekend day in the UK, a full set of correlation terms (ten) can be estimated. For France, because time diaries were only collected on one day, we are unable to measure how his (her) time is correlated (in the unobservables) between weekend and weekday days or to measure how his time on one type of day is correlated with her time on the other type of day. This means we can estimate only six correlation terms.

\section{Results}

The estimated price effects are presented in Table 3. Panel A reports the results for Great Britain $^{15}$ and Panel B those for France. Appendix Table A1 presents the other covariate results for Great Britain and Appendix Table A2 does the same for France. Table 4 presents correlations coefficients for France and Great Britain.

\footnotetext{
${ }^{15}$ The final estimation sample for Great Britain excludes 12 households in which the male respondent was disabled, as none of these households purchased maid service, resulting in perfect collinearity in the Probit equation. Results were robust to including these households and dropping the indicator for male disability.
} 
The first rows of Table 3 present results for the Probit equation for maid service. Both coefficient estimates and marginal effects are reported. These marginal effects are calculated for married couples with sample average wages, sample average ages, and one teenage child. All other covariates are assumed to take a value of zero. These covariate values generate a predicted probability of maid service of $3.4 \%$ in the UK and of $2.1 \%$ in France. The price effects indicate that in both the UK and France, maid service is negatively related to its own price (though not significantly so), positively related to both partners' wages, and positively related to the presence of non-labor income. In particular, the wage of the wife is significant at the one per cent level in both countries and has the largest absolute price affect. A one percent increase in her wage is associated with an almost 10 percentage point increase in the probability of hiring a maid in the UK and a 7 percentage point increase in the probability of hiring a maid in France. These marginal effects are substantial in light of the base probability of hiring a maid of 2-3\%. The wage of the husband has a positive effect in both countries, though it is significant only at the ten per cent level in France (at the 5 per cent level in Great Britain). A one percent increase in his wage is associated with an 8 percentage point increase in the probability of hiring a maid in Great Britain and a 2 percentage point increase in France. Receipt of non-labor is highly significantly related to the probability of hiring a maid in both countries, having a marginal impact of about 2 percentage points in both countries. The wage of the maid has a negative impact as expected, but though its marginal effect is rather large $(14.5 \%$ in the UK and $5 \%$ in France) its effect is not precisely estimated. The cross-country similarities are striking.

Strong similarities persist in the partners' housework time equations. Looking first at results in the first column, the market price of domestic services has a substantial and consistently positively relation to his and her housework time on weekends. This relation is 
statistically significant at the $1 \%$ level in the UK and has a p-value of 0.16 in France for men's weekend time. The magnitude of the impact suggests that a $1 \%$ increase in the market price of domestic services increases his weekend time on housework by 2 hours in the UK and almost 1 hour in France. The fact that the time devoted to household production on the weekends is more sensitive to market prices than the time devoted on weekdays is reasonable. Maids typically visit only once a week or once every two weeks and thus likely perform tasks that need not be performed every day, but can be left to the weekend. That the relation is more significant for men than for women suggests that men are more likely to be burdened with these tasks when maid service is more expensive - while women perform them anyway.

Men's wages have no significant relation to partners' reported housework time in either country. The non-labor income dummy is not much more significant than his wage. However, the results suggest that the presence of non-labor income in France is associated with women reducing their weekend housework time by just over 20 minutes - an association that is statistically significant at the $5 \%$ level.

The most significant relation in both countries is between her wage and housework time. This relation is statistically significant at the $5 \%$ level or better in all four equations in France and in two of four equations in the UK. Specifically, an increase in her wages is associated with an increase in his housework time and a decrease in her housework time. A $1 \%$ increase in her wage is associated with a 24 minute increase in his housework time on weekends in the UK and with a 22 minute weekend and a 9 minute weekday increase in his housework time in France. Similarly a $1 \%$ increase in her wage is associated with a decrease of 32 minutes in her time on housework on weekdays in the UK and with a decrease of 90 (45) minutes in her weekday (weekend) time in France. These constitute substantial effects. 
As far as other covariates go, little affects the probability of hiring services from the market in the UK, except for cohabitant status of the couple and minority status of the man. Both are significant at the ten per cent level and negative, indicating that unmarried partners and households with men from a minority group are somewhat less likely to purchase help. The presence of children aged three to ten years and an older husband are positively and a husband in poor health is negatively and significantly associated with purchasing help from the market in France. The domestic time of British men also appears quite insensitive to the other covariates; those having a University degree do more and those residing in London do less housework (almost 20 minutes less) on weekends. For French men, residing in Paris also significantly reduces the housework done on weekends - by about 30 minutes. Having an older wife further reduces his time on weekends while on weekdays men in France do more housework if they are cohabiting and less if there is another adult in the household.

In contrast, the time devoted to housework by French and UK women is quite sensitive to the covariates. 'Her' chore time in both countries increases significantly on weekdays with the presence of other adults and children of any age, with most of these covariates significant at the $1 \%$ level. On weekends, it is the presence of older children (age 6-9 in France and 5+ in the UK) that is associated with an increase in women's housework time. While her housework time is not sensitive to residence in Paris/London, it is significantly lower on all days for French women who are cohabiting. Own age and education as well as minority status also play a role.

Finally, this formulation allows us to estimate cross-equation correlations between the unobservables (see Table 4). For both countries we are able to estimate how the residuals in the equation modeling the decision to purchase domestic services are related to the residuals from each housework time equation. These are notable for their statistical insignificance in both 
countries and on all days for men. Purchased services and her weekend time are also not correlated in the unobservables. In contrast, the unobservables affecting purchased domestic services and her domestic time on weekdays are negatively and highly statistically significantly correlated in both countries.

Also estimable in both countries are the correlations between partners and within day type. Here we find that the correlations between the unobservables affecting his and her domestic work are positive on weekends and negative on weekdays. This relation is statistically significant in France on weekends and in the UK on weekdays. Weekend schedules are less likely impacted by employment schedules and the positive relation on weekends may reflect common preferences for home produced goods or possibly shared production time. There is often less flexibility on weekday schedules and housework performed on these days may 'need' to be performed on these days. The negative relation in the unobservables may indicate that what one partner does on a weekday spares the other partner from the task. Thus, partners are substitutes on weekdays and complements on weekends as regards housework time.

As the French data include housework time for either a weekend or a weekend day and never for both, it is not possible to estimate any relation between different days either for a single individual or between partners. The UK data provide estimates of these correlation terms. These estimates indicate that individuals who spend more time on housework on weekends for unobservable reasons are also likely to spend more time on housework on weekdays for unobservable reasons. These positive correlations could be the result of a number of different mechanisms. For example, they could reflect preferences over home production or productivity in home production. Between partner, between day correlations are consistently negative and statistically significant (though only at the $10 \%$ level for her weekend and his weekday chores). 
Thus, when he (she) reports more time on a weekend day for unobservable reasons, she (he) reports less time on a weekday day.

Several alternative specifications were estimated to examine the robustness of the estimates. We re-estimated the model using a broader measure of housework that included food preparation, shopping, and doing administrative tasks. The results indicated that our estimates of "price" effects, i.e. the effects of his and her wage and the price of market domestic services, are robust to this alternative specification. In particular, their sign and significance level are generally unaffected. The price of maid service becomes significantly positively associated with his weekend housework time in both countries when more tasks are counted as housework, but loses significance in her weekend housework equation for the UK. Her wage loses significance as a determinant of his weekend time in France and nonlabor income just barely loses significance as a determinant of her weekend time in France. In the UK, the correlation between his and her weekend time becomes insignificant, while the negative correlation between his weekend and her weekday time becomes significant suggesting perhaps that men take up some slack on weekends by performing other types of housework.

Results are also robust to other sensitivity checks. Modeling the domestic service time purchased in the market using a Tobit rather than a Probit specification yielded essentially the same results; with the remarkable exception that using a Tobit specification the price of maid services becomes statistically significant in France, suggesting that the price of maid services affects the quantity bought more than the choice of buying such services or not. We experimented with different measures of the price of maid service (see data section) as we believe the weak significance of this variable is largely attributable to its poor measurement, but 
these alternative measures were no better. Adding equations for his and her usual hours of market work to more explicitly control for time constraints yielded no new insights either.

\section{Conclusion}

We use time-diary data from couple households in the UK and France to estimate a model of demand for domestic services. The decision to purchase maid services is modeled jointly with the time allocated by each partner on weekend and weekday days to household chores. We limit the analysis to those household chores that are routine, are commonly performed by maid services, and are not likely to directly enter a household's utility function as enjoyable activities. The latter restriction is corroborated by an examination of preferences as reported in our samples. The domestic services modeled include house cleaning, laundry, and ironing. Our findings are robust to the use of a broader definition of housework, including additionally cooking, shopping, and doing administrative paper work.

We focus on the impact prices (the price of maid service, the opportunity cost of time of each partner as measured by market wages, and the availability of non-labor income) have on input demand. The results indicate that the decision to purchase maid service is negatively related to the price of maid service and positively related to each partner's wage and the availability of non-labor income. Women's wages have the strongest marginal effect, with a $1 \%$ increase in her wages associated with a $10 \%$ increase in the probability of hiring a maid in the UK and a 7\% increase in France. The association with men's wages is of a smaller magnitude ( $8 \%$ in the UK and $2 \%$ in France). The substantially weaker association with men's wages in France may be attributable to the substantially greater gender differential in reported housework time in France. French men spend much less time on housework than French women and thus 
may feel less inclined to finance a substitute service. As might be expected if maids perform housework tasks that can be put off or delayed, the price of maid service is more closely associated with weekend housework time than with weekday housework time. The estimated impacts of the price of maid service on household time inputs are not precise, a result which is likely attributable to the use of a measure that varies very little within each survey. There is in addition in both countries a strong negative correlation between the residuals from the probit on maid services and the time women report spending on housework on weekdays, suggesting there is also a latent relation between 'her' weekday time and maid service.

A few other results are worth highlighting. First, it is of some interest to note that while the time women spend on housework varies considerably across the sample, most notably with family composition, the same is not true for men. This finding is akin to that reported in Hersch and Stratton (1997) who estimate a housework time equation for couples in the US. They found that not only was there little variation in reported housework time for men within a cross-section, but that this time varied very little over time as well. The positive association between her earning power and his housework time found here may reflect her negotiating power. Second, while there is no significant difference in reported housework time between married and cohabiting couples in the UK, in France it is quite clear that he does more housework (at least on weekdays) and that she does less when the couple is not legally married.

As time not devoted to household chores is freed for other uses, the policy implications of this work are manifold. In particular, to the extent that maid service is a better substitute for her housework time, subsidizing the domestic help industry could help support women's increased labor force participation. The French government has in fact since the nineties passed a number of measures aimed at promoting the domestic help industry, notably by allowing households to 
deduct from taxes part of the cost of domestic help. We do not, however, find evidence that French households purchase more market services than UK households, thus supporting Flipo, Fougere, and Olier's (2007) finding that only a minority of very rich households benefited from the policy. A generalized domestic services price subsidy might have a greater impact. Alternatively our results suggest that tying these subsidies to 'her' earnings power might have the greatest impact as she appears more likely to benefit and more inclined to hire such services. Thus, while 'her' time is currently the dominant input to domestic services, 'her' opportunity cost of time has the most significant and substantial impact on the inputs. 


\section{References}

Aguiar, Mark and Erik Hurst. (2005). "Consumption versus Expenditure." Journal of Political Economy, Vol. 113, No 5, pp. 919-948.

Baxter, Janeen, Belinda Hewitt, and Mark Western. (2009), "Who Uses Paid Domestic Labor in Australia? Choice and Constraint in Hiring Household Help." Feminist Economics, Vol. 15, No. 4, pp. 1-26.

Bianchi Suzanne, Melissa Milkie, Liana Sayer and John P. Robinson. (2000). "Is Anyone Doing the Housework? Trends in the Gender Division of Household Labor." Social Forces, Vol. 79, No. 1, pp. 191-228.

Bloemen, Hans G. and Elena F. G. Stancanelli. (2008). "How do spouses allocate time: the impact of wages and income." IZA DP No. 3679 (September).

Bonke Jens, Mette Deding, Mette Lausten and Leslie S. Stratton. (2008). "Intra-Household Specialization in Housework in the United States and Denmark." Social Science Quarterly, Vol. 89, No. 4, pp. 1023-1043.

Cohen, Philip N. (1998). "Replacing Housework in the Service Economy: Gender, Class, and Race-Ethnicity in Service Spending." Gender \& Society, Vol. 12, No. 2, pp. 219-231.

Connelly, Rachel and Jean Kimmel. (2009). "Spousal influences on parents' non-market time choices." Review of Economics of the Household, Vol. 7, No. 4 (December), pp. 361-394.

Cortes, Patricia and Jessica Y. Pan. (2009). " Outsourcing Household Production: The Demand for Foreign Domestic Helpers and Native Labor Supply in Hong Kong.” University of Chicago, mimeo.

Hamermesh, Daniel. (2007). "Time to Eat: Household Production under Increasing Income Inequality." American Journal of Agricultural Economics, Vol. 89, No. 4, pp. 852-863.

Flipo, Anne, Denis Fougere, and Lucile Olier. (2007). "Is the Household Demand for In-Home Services Sensitive to Tax Reductions? The French Case." Journal of Public Economics, Vol. 91, pp. 365-385.

Flipo, Anne. (1996). "Les services de proximite de la vie quotidienne." INSEE premiere, Vol. 491, Paris.

Gupta Sanjiv and Michael Ash. (2008). "Whose Money, Whose Time? A non-parametric approach to modeling time spent on housework in the United States." Feminist Economics, Vol. 14, No. 1 (January), pp. 93-120.

Goldschmidt-Clermont, Luisella and Elisabett Pagnossin-Aligisakis. (1999). "Households' Non-SNA Production: Labour Time, Value of Labour and of Product, and Contribution 
to Extended Private Consumption." Review of Income and Wealth, Series 45, No. 4 (December), pp. 519-529.

Hersch, Joni and Leslie S. Stratton. (1997). "Housework, Fixed Effects, and Wages of Married Workers." Journal of Human Resources, Vol. 32, No. 2 (Spring), pp. 285-307.

Krantz-Kent, Rachel. (2009), "Measuring Time Spent in Unpaid Household Work: Results from the American Time Use Survey." Monthly Labor Review. Vol. 132, No. 7 (July), pp. 4659.

Juster, F. Thomas. (1985). "The Validity and Quality of Time Use Estimates Obtained from Recall Diaries." In: F. Thomas Juster and Frank P. Stafford (eds.) Time, Goods, and Well-Being. Survey Research Center, Institute for Social Research, University of Michigan, Ann Arbor, Michigan, pp. 63-91.

Kimmel, Jean and Rachel Connelly. (2007). "Mothers' Time Choices: Caregiving, Leisure, Home Production, and Paid Work.” Journal of Human Resources, Vol. 42, No. 3, pp. 643-681.

Landefeld, J. Steven and Stephenie H. McCulla. (2000). "Accounting for Nonmarket Household Production within a National Accounts Framework." Review of Income and Wealth, Series 46, No. 3 (September), pp. 289-307.

Pollak, Robert A. (2005). "Bargaining Power in Marriage: Earnings, Wage Rates and Household Production.” NBER Working Paper No. 11239 (March).

Pollak, Robert A. (2010). "Individuals' Technologies and Household Technology.” Washington University in St. Louis, mimeo.

Roodman, David. (2009). "Estimating Fully Observed Recursive Mixed-Process Models with cmp.” Working Papers 168, Center for Global Development.

Roodman, David. (2007). "CMP: Stata module to implement conditional (recursive) mixed process estimator." Statistical Software Components S456882, Boston College Department of Economics, revised 22 May 2009.

Sousa-Poza, Alfonso, Hans Schmid, and Rolf Widmer. (2001). "The Allocation and Value of Time Assigned to Housework and Child-Care: An Analysis for Switzerland. " Journal of Population Economics, Vol. 14, No. 2 (December), pp. 599-618.

Stewart, Jay. (2009). “Tobit or Not Tobit?” IZA Discussion Paper 4588.

Wing, Suen. (1994). "Market-procured housework: The demand for domestic servants and female labor supply." Labour Economics, Vol. 1, No. 3-4 (September), pp. 289-302. 
Figure 1: Preferences Regarding Housework Activities

By Country, Gender, and Activity Type

A. Great Britain
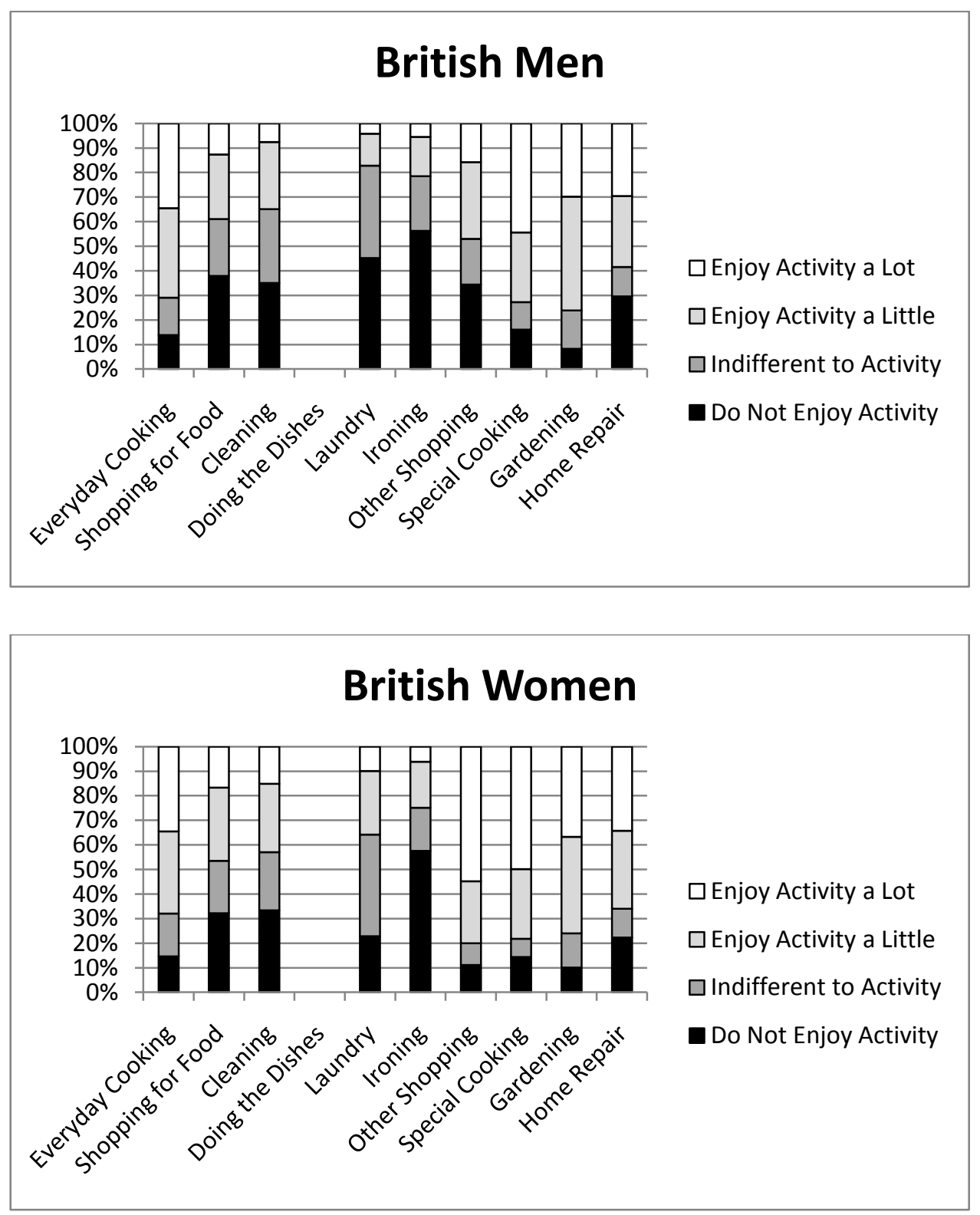
Figure 1: Continued

B. France
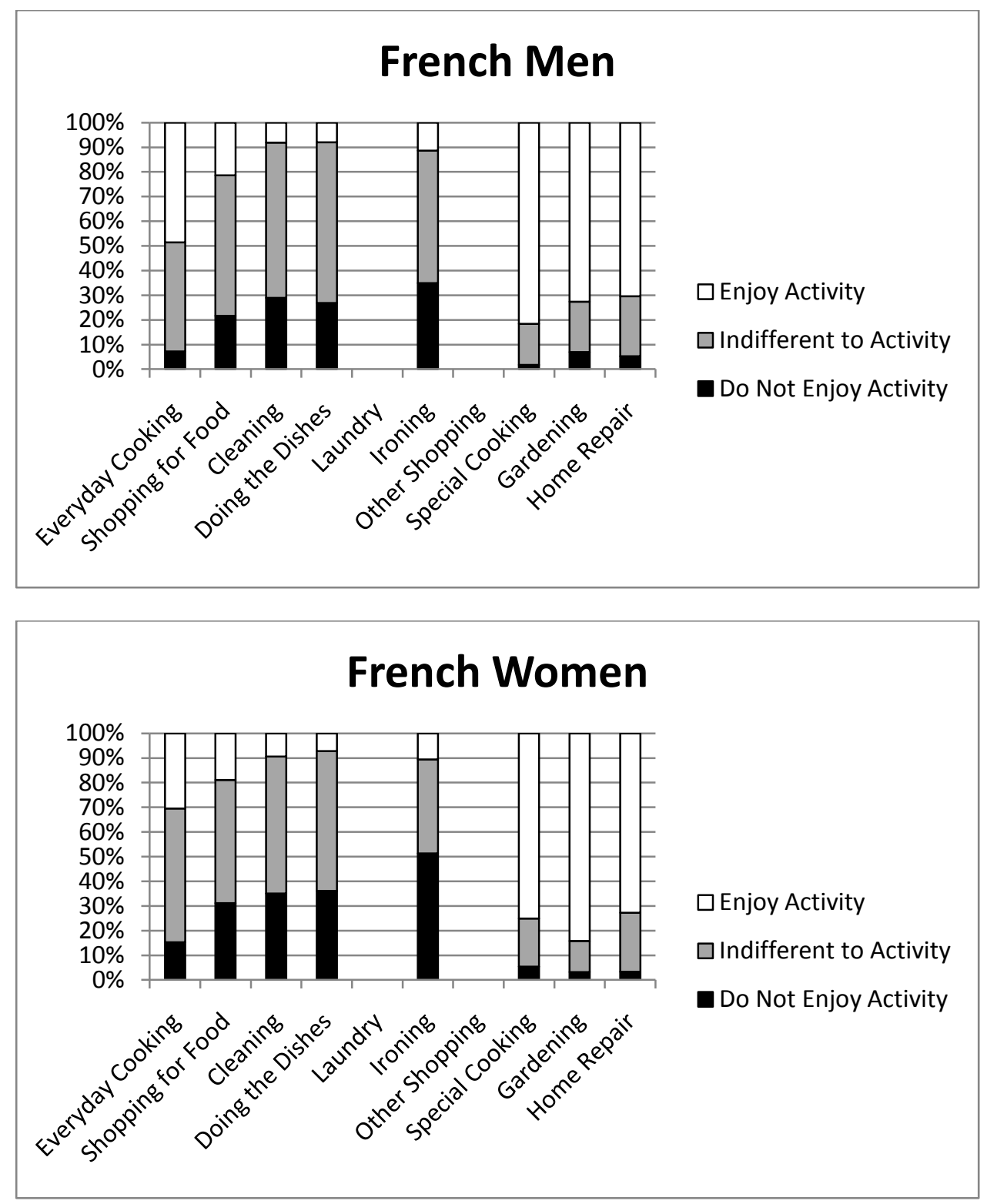
Figure 2: Distribution of Time Spent on Housework

Preferred definition (cleaning, laundry, ironing)

By Country, Gender, and Day of Week

A. Great Britain
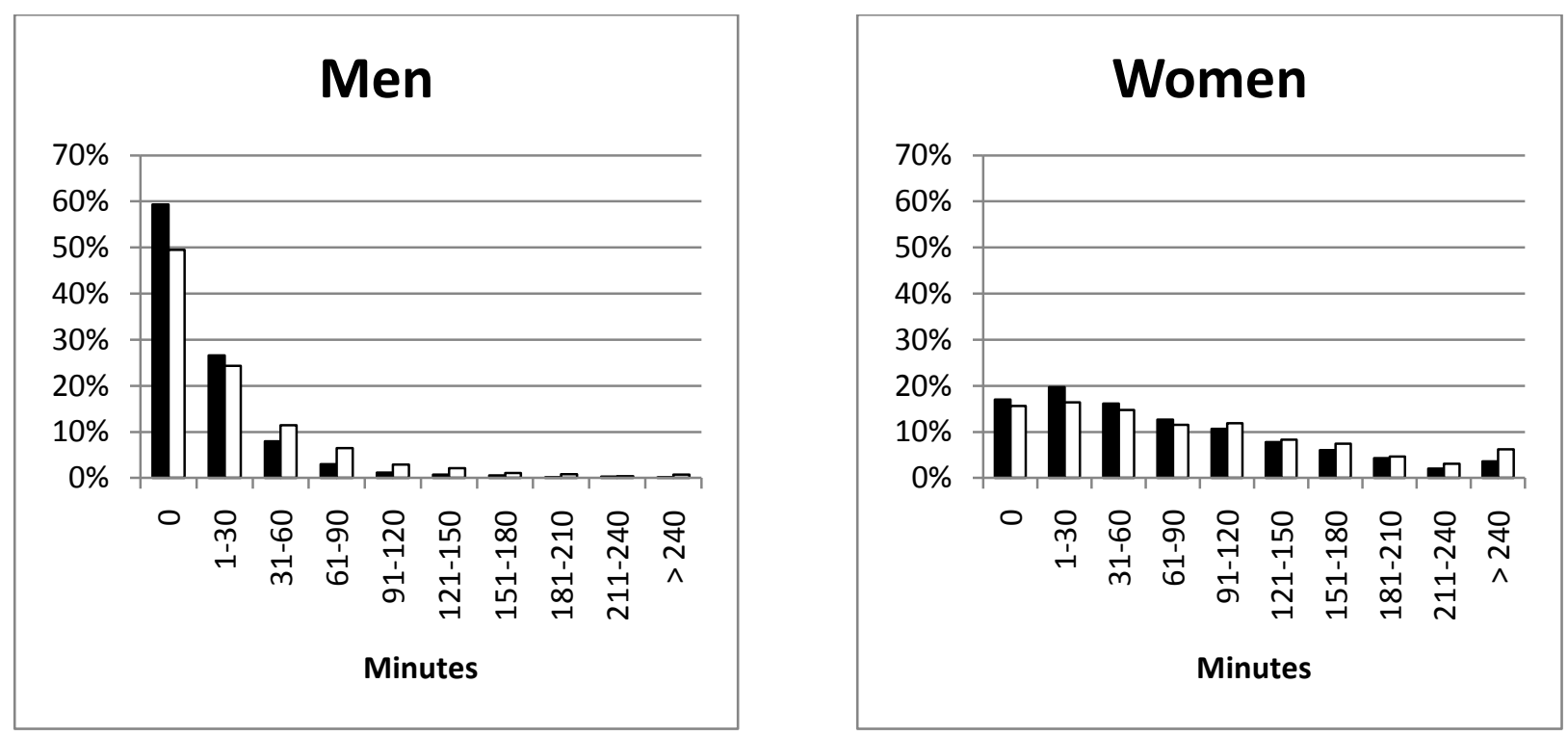

B. France
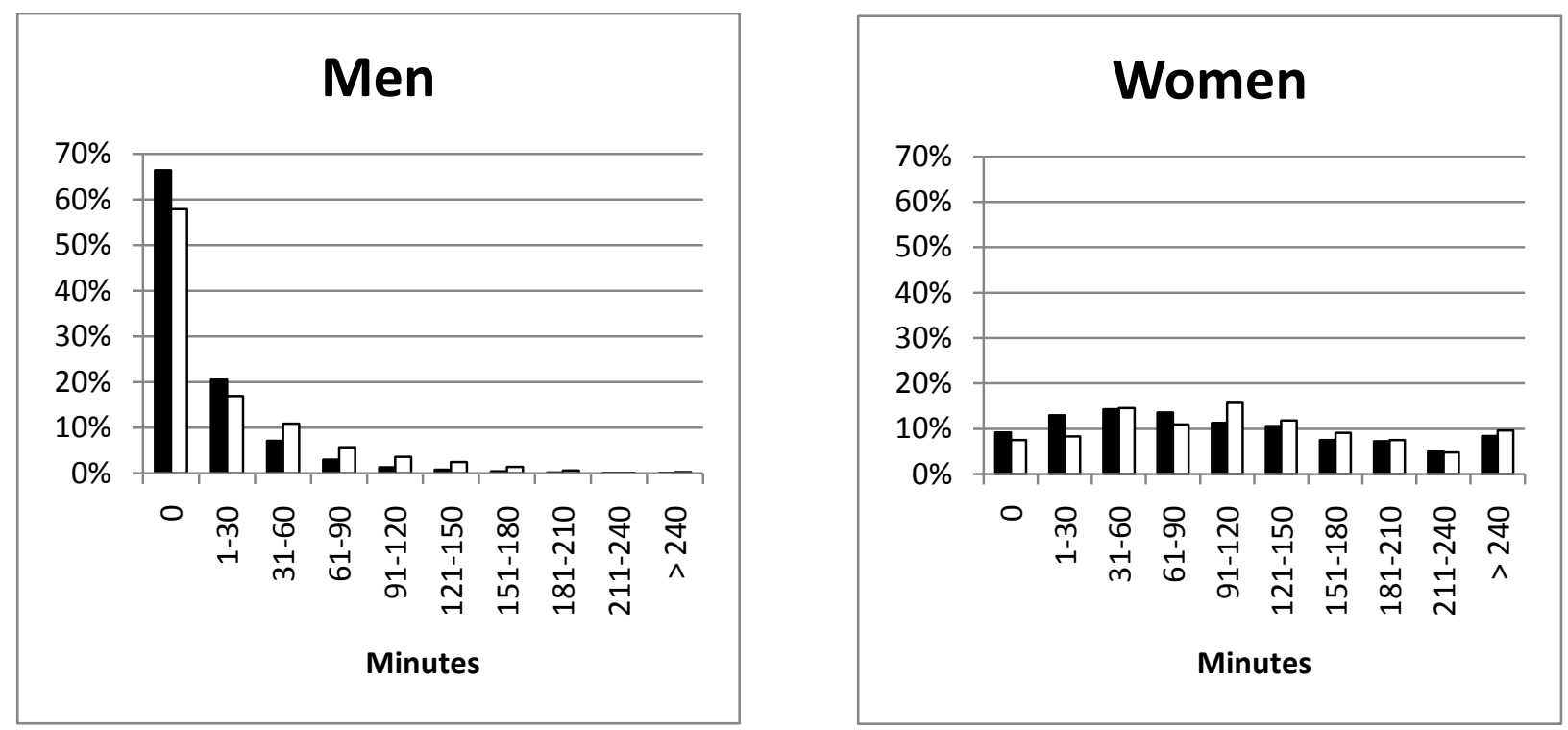

Black indicates Weekday. White indicates Weekend. 


\section{Table 1: Distribution of Purchased Housework Time By Country}

Time

(Minutes/Day)

Great Britain $\quad$ France

0

$0-10$

$10-20$

$20-40$

$40-60$

$>60$

Sample Size
$93.4 \%$

$1.2 \%$

$1.7 \%$

$1.6 \%$

$1.1 \%$

$1.0 \%$

1290
$92.3 \%$

$0.41 \%$

$1.13 \%$

$2.90 \%$

$1.57 \%$

$1.69 \%$

2924 


\section{Table 2: Summary Statistics}

\begin{tabular}{|c|c|c|c|c|}
\hline \multirow[b]{2}{*}{ Variable } & \multicolumn{2}{|c|}{ British } & \multicolumn{2}{|c|}{ French } \\
\hline & Mean & Std. Dev. & Mean & Std. Dev. \\
\hline Man's imputed log wage & 1.74 & 0.24 & 4.08 & 0.32 \\
\hline Woman's imputed log wage & 1.51 & 0.25 & 3.84 & 0.32 \\
\hline Maid's log median wage & 1.61 & 0.04 & 3.52 & 0.06 \\
\hline Receives some non-labor income & 0.27 & 0.44 & 0.16 & 0.37 \\
\hline Lives in London/Paris & 0.07 & 0.25 & 0.02 & 0.15 \\
\hline Summer & 0.25 & 0.43 & 0.12 & 0.33 \\
\hline Cohabits & 0.18 & 0.38 & 0.21 & 0.41 \\
\hline Number of other persons age $17+$ & 0.28 & 0.60 & 0.42 & 0.75 \\
\hline Presence of child age $0-2$ & 0.17 & 0.37 & 0.16 & 0.37 \\
\hline Presence of child age $3-4^{*}$ & 0.12 & 0.32 & 0.16 & 0.37 \\
\hline Presence of child age $5-9 *$ & 0.25 & 0.43 & 0.28 & 0.45 \\
\hline Presence of child age $10-16$ & 0.31 & 0.46 & 0.32 & 0.47 \\
\hline Woman is minority & 0.03 & 0.18 & 0.06 & 0.23 \\
\hline Woman is in poor health & 0.02 & 0.15 & 0.02 & 0.12 \\
\hline Woman has a university degree & 0.14 & 0.34 & 0.10 & 0.30 \\
\hline Woman's age & 38.92 & 9.57 & 39.3 & 8.90 \\
\hline Man is minority & 0.04 & 0.20 & 0.06 & 0.23 \\
\hline Man is in poor health & 0.01 & 0.11 & 0.02 & 0.13 \\
\hline Man has a university degree & 0.14 & 0.34 & 0.12 & 0.33 \\
\hline Man's age & 40.92 & 9.53 & 41.65 & 8.93 \\
\hline Observations & 1290 & & 2924 & \\
\hline
\end{tabular}




\section{Table 3 Price Effects}

\section{Panel A: UK Results}

\begin{tabular}{|c|c|c|c|c|c|c|c|}
\hline$\underline{\text { Explanatory variables }}$ & $\begin{array}{l}\text { Maid's log } \\
\text { median wage }\end{array}$ & & $\begin{array}{l}\text { His imputed } \\
\text { log wage }\end{array}$ & & $\begin{array}{l}\text { Her imputed } \\
\text { log wage }\end{array}$ & & $\begin{array}{l}\text { Non-labor } \\
\text { income dummy }\end{array}$ \\
\hline Dependent variable & $\underline{\text { Coeffic. }}$ & & $\underline{\text { Coeffic. }}$ & & $\underline{\text { Coeffic. }}$ & & $\underline{\text { Coeffic. }}$ \\
\hline \multirow[t]{3}{*}{ Maid Service } & -1.8135 & & 0.9646 & $* *$ & 1.2405 & $* * *$ & 0.2780 \\
\hline & $(2.2021)$ & & (0.3989) & & $(0.3902)$ & & $(0.1342)$ \\
\hline & {$[-0.1451]$} & & [0.0772] & & [0.0992] & & [0.0222] \\
\hline \multicolumn{8}{|l|}{ His Housework Time } \\
\hline \multirow[t]{2}{*}{ On Weekends } & 2.0186 & $* * *$ & -0.0976 & & 0.4010 & $* * *$ & 0.0132 \\
\hline & $(0.7800)$ & & $(0.1534)$ & & $(0.1413)$ & & $(0.0506)$ \\
\hline \multirow[t]{2}{*}{ On Weekdays } & 0.0612 & & 0.0234 & & 0.0213 & & 0.0538 \\
\hline & $(0.5460)$ & & $(0.1061)$ & & $(0.1222)$ & & $(0.0391)$ \\
\hline \multicolumn{8}{|l|}{ Her Housework Time } \\
\hline \multirow[t]{2}{*}{ On Weekends } & 1.6780 & & -0.4292 & & 0.3160 & & 0.0159 \\
\hline & $(1.3157)$ & & $(0.2837)$ & & $(0.2277)$ & & $(0.0929)$ \\
\hline \multirow[t]{2}{*}{ On Weekdays } & -0.3240 & & -0.1512 & & -0.5325 & $* *$ & 0.0283 \\
\hline & (1.0074) & & $(0.2512)$ & & $(0.2281)$ & & $(0.0717)$ \\
\hline
\end{tabular}




\section{Panel B: French Results}

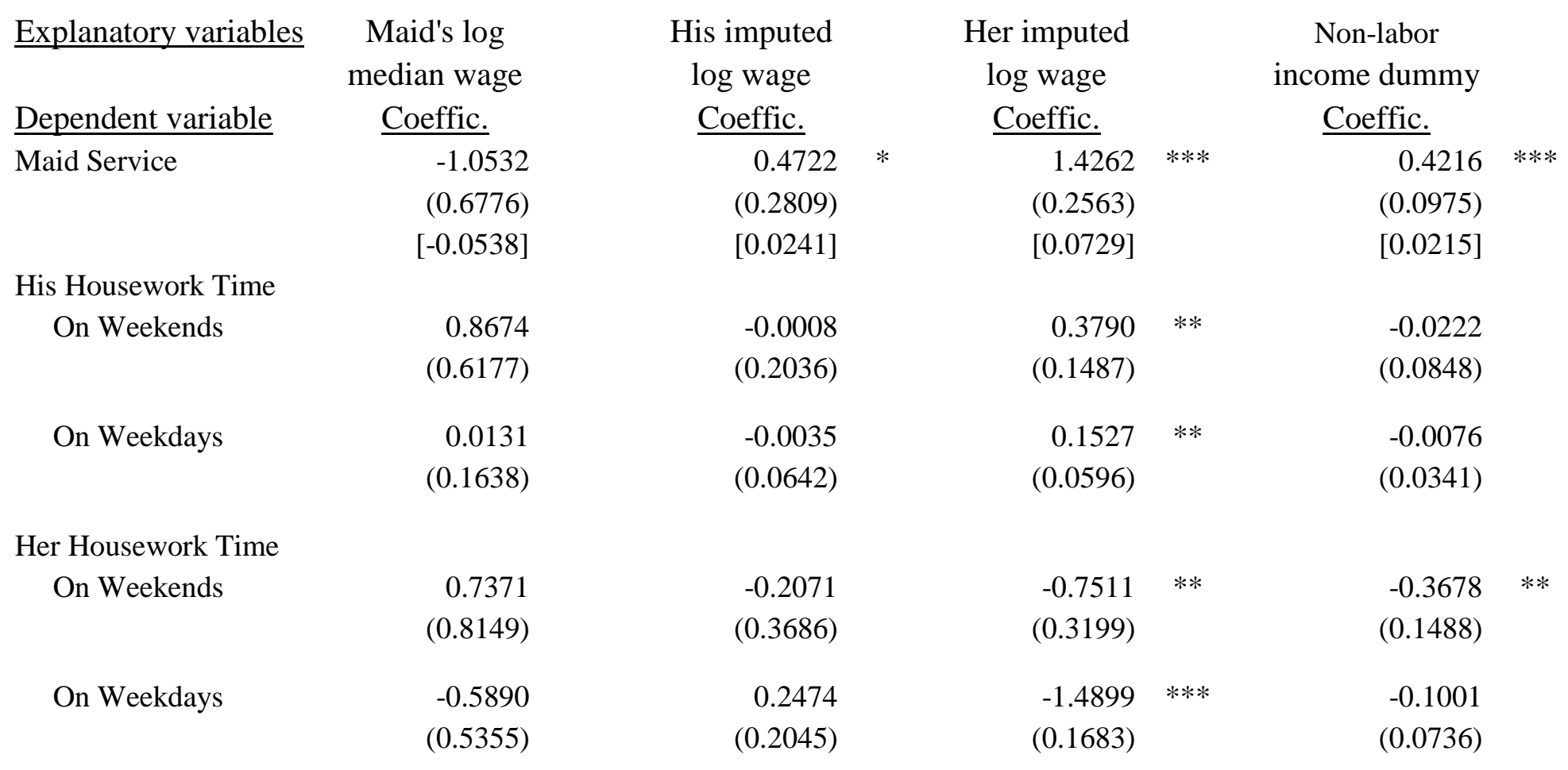

Standard errors in parentheses. Marginal effect in brackets.

Also included in the specification are dummy variables to identify those living in London (Paris), those cohabiting, the presence of children of various ages, individuals who are in poor health, and a summer interview; a continuous measure of the number of other adults in the household; and the age, university degree status, and minority status for each partner. 


\section{Table 4 Correlations}

Panel A: UK

His Housework Time
On Weekends
On Weekdays
Her Housework Time
On Weekends

On Weekdays

Panel B: France

His Housework Time
On Weekends
On Weekdays
Her Housework Time
On Weekends
On Weekdays

\begin{tabular}{|c|c|}
\hline Maid Service & On Weekends \\
\hline $\begin{array}{r}0.0404 \\
(0.0469)\end{array}$ & \\
\hline $\begin{array}{c}-0.0721 \\
(0.0758)\end{array}$ & $\begin{array}{r}0.2181 \\
(0.0287)\end{array}$ \\
\hline
\end{tabular}

\begin{tabular}{|c|c|c|c|c|c|c|c|}
\hline-0.0039 & & 0.0458 & & -0.0478 & $*$ & & \\
\hline$(0.0637)$ & & $(0.0439)$ & & $(0.0289)$ & & & \\
\hline $\begin{array}{r}-0.1670 \\
(00596)\end{array}$ & $* * *$ & $\begin{array}{l}-0.0598 \\
(00269)\end{array}$ & $* *$ & -0.1388 & $* * *$ & 0.1264 & $* * *$ \\
\hline
\end{tabular}

Her Housework Time

On Weekends $\underline{\text { On Weekdays }}$

$$
\text { (0.0276) }
$$

$$
\begin{gathered}
\text { Maid Service } \\
-0.0200 \\
(0.0897) \\
-0.0731 \\
(0.0575)
\end{gathered}
$$

His Housework Time

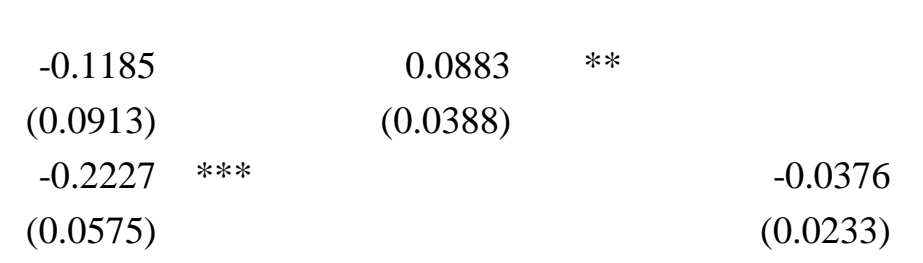


Appendix Table A1: Other Covariates for Home Production Inputs

United Kingdom

$\begin{array}{lr}\text { Dependent variables: } & \text { Maid Service } \\ \text { Explanatory Variables } & \text { Coeffic. } \\ \text { Lives in London } & 0.0913 \\ \text { Cohabits } & (0.3268) \\ & -0.3442 \\ \text { Number of persons age 17+ } & (0.2054) \\ \text { Presence of child age } 0-2 & 0.1175 \\ & (0.0942) \\ \text { Presence of child age 3-4 } & 0.1656 \\ \text { Presence of child age 5-9 } & (0.1709) \\ \text { Presence of child age 10-16 } & 0.2177 \\ \text { Summer } & (0.2001) \\ \text { Woman's age } & -0.1202 \\ \text { Woman has a university degree } & (0.1550) \\ \text { Woman is in poor health } & -0.0447 \\ & (0.1359) \\ & -0.0744 \\ & (0.1372) \\ & 0.0145 \\ & (0.0146) \\ & 0.1836 \\ & (0.2281) \\ & 0.1699 \\ & (0.3150) \\ & \end{array}$

His Housework Time

On Weekends On Weekdays

\begin{tabular}{c} 
Coeffic. \\
\hline-0.3213 \\
$(0.1193)$ \\
-0.0390 \\
$(0.0527)$ \\
0.0207 \\
$(0.0426)$ \\
0.0283 \\
$(0.0585)$ \\
0.0698 \\
$(0.0605)$ \\
0.0323 \\
$(0.0618)$ \\
0.0501 \\
$(0.0529)$ \\
-0.0283 \\
$(0.0479)$ \\
-0.0004 \\
$(0.0046)$ \\
-0.1001 \\
$(0.0991)$ \\
-0.1145 \\
$(0.1364)$ \\
\end{tabular}

Her Housework Time

On Weekends On Weekdays

\begin{tabular}{rrrrl}
\multicolumn{1}{c}{ Coeffic. } & Coeffic. & Coeffic. & \\
\hline 0.0113 & -0.3325 & 0.1095 & \\
$(0.0880)$ & $(0.2358)$ & $(0.1750)$ & \\
-0.0021 & -0.0517 & -0.1494 & \\
$(0.0448)$ & $(0.0988)$ & $(0.0964)$ & \\
-0.0202 & 0.0195 & 0.1558 & $* *$ \\
$(0.0254)$ & $(0.0779)$ & $(0.0771)$ & \\
0.0487 & 0.0558 & 0.4668 & $* * *$ \\
$(0.0458)$ & $(0.1055)$ & & $(0.0991)$ & \\
0.0136 & 0.1401 & & 0.4292 & $* * *$ \\
$(0.0573)$ & $(0.1259)$ & & $(0.1180)$ & \\
0.0483 & 0.1690 & $*$ & 0.3482 & $* * *$ \\
$(0.0432)$ & $(0.1018)$ & $(0.0876)$ & \\
-0.0058 & 0.3072 & $* * *$ & 0.1823 & $* *$ \\
$(0.0344)$ & $(0.1072)$ & & $(0.0875)$ & \\
-0.0306 & 0.0035 & & -0.0150 & \\
$(0.0317)$ & $(0.0921)$ & & $(0.0790)$ & \\
-0.0003 & 0.0131 & & 0.0235 & $* * *$ \\
$(0.0035)$ & $(0.0100)$ & $(0.0083)$ & \\
-0.0585 & -0.4261 & $* * *$ & -0.0760 & \\
$(0.0662)$ & $(0.1484)$ & $(0.1356)$ & \\
0.0797 & -0.3514 & 0.0270 & \\
$(0.1442)$ & $(0.2241)$ & $(0.2293)$ &
\end{tabular}




\begin{tabular}{|c|c|c|c|c|c|c|c|c|}
\hline Woman is minority & $\begin{array}{r}0.5427 \\
(0.3414)\end{array}$ & & $\begin{array}{r}-0.1736 \\
(0.1617)\end{array}$ & & $\begin{array}{r}-0.0016 \\
(0.0858)\end{array}$ & $\begin{array}{r}-0.2460 \\
(0.3633)\end{array}$ & & $\begin{array}{r}0.1427 \\
(0.2005)\end{array}$ \\
\hline \multirow[t]{2}{*}{ Man's age } & -0.0005 & & 0.0008 & & 0.0027 & 0.0072 & & 0.0022 \\
\hline & $(0.0148)$ & & $(0.0050)$ & & $(0.0040)$ & $(0.0098)$ & & $(0.0085)$ \\
\hline \multirow[t]{2}{*}{ Man has a university degree } & -0.3204 & & 0.2080 & $* *$ & 0.0449 & 0.0548 & & -0.0713 \\
\hline & $(0.2205)$ & & $(0.0987)$ & & $(0.0673)$ & $(0.1549)$ & & $(0.1402)$ \\
\hline \multirow[t]{2}{*}{ Man is minority } & -0.7014 & $*$ & -0.0126 & & -0.0749 & 0.5740 & $*$ & -0.2196 \\
\hline & $(0.3758)$ & & $(0.1675)$ & & $(0.0795)$ & $(0.2944)$ & & $(0.2015)$ \\
\hline \multirow[t]{2}{*}{ Constant } & -2.9225 & & -3.2534 & $* * *$ & -0.0291 & -1.8011 & & 1.6149 \\
\hline & $(3.5571)$ & & $(1.2315)$ & & $(0.8551)$ & $(2.1328)$ & & $(1.6560)$ \\
\hline
\end{tabular}

Standard errors in parentheses.

Asterisks indicate significance using a 2 -tailed test: $* * * 1 \%, * * 5 \%, * 10 \%$. 
Appendix Table A2: Other Covariates for Home Production Inputs

France

\begin{tabular}{|c|c|c|c|c|c|c|}
\hline \multirow[b]{2}{*}{ Dependent variables: } & \multirow[b]{2}{*}{ Maid Service } & \multicolumn{2}{|c|}{ His Housework Time } & \multicolumn{3}{|c|}{ Her Housework Time } \\
\hline & & On Weekends & On Weekdays & On Weekends & On Weekd & lays \\
\hline Explanatory Variables & Coeffic. & Coeffic. & Coeffic. & Coeffic. & Coeffic. & \\
\hline \multirow[t]{2}{*}{ Lives in Paris } & 0.2024 & $-0.4781 \quad * * *$ & -0.0351 & -0.3953 & -0.1560 & \\
\hline & $(0.2120)$ & $(0.1651)$ & $(0.0688)$ & $(0.3028)$ & $(0.1929)$ & \\
\hline \multirow[t]{2}{*}{ Cohabits } & 0.1084 & 0.0902 & $0.1090 * * *$ & $-0.2729 * *$ & -0.2736 & $* * *$ \\
\hline & $(0.1150)$ & $(0.0847)$ & $(0.0371)$ & $(0.1318)$ & $(0.0826)$ & \\
\hline \multirow[t]{2}{*}{ Number of persons age $17+$} & 0.0412 & -0.0636 & -0.0277 & 0.0506 & 0.1599 & $* * *$ \\
\hline & $(0.0696)$ & $(0.0390)$ & $(0.0148)$ & $(0.0798)$ & $(0.0584)$ & \\
\hline \multirow{2}{*}{ Presence of child age $0-2$} & 0.1736 & -0.0334 & 0.0084 & 0.0590 & 0.1970 & $* *$ \\
\hline & $(0.1527)$ & $(0.0908)$ & $(0.0314)$ & $(0.1491)$ & $(0.0866)$ & \\
\hline \multirow[t]{2}{*}{ Presence of child age 3-5 } & $0.2299 * *$ & 0.0561 & 0.0039 & 0.1869 & 0.2596 & $* * *$ \\
\hline & $(0.1121)$ & $(0.0718)$ & $(0.0385)$ & $(0.1560)$ & $(0.0825)$ & \\
\hline \multirow[t]{2}{*}{ Presence of child age 6-9 } & $0.2988 * * * *$ & 0.0460 & 0.0136 & 0.2251 & 0.2721 & $* * *$ \\
\hline & $(0.0880)$ & $(0.0648)$ & $(0.0247)$ & $(0.1277)$ & $(0.0752)$ & \\
\hline \multirow[t]{2}{*}{ Presence of child age $10-16$} & 0.0230 & -0.0377 & -0.0198 & 0.1032 & 0.3055 & $* * *$ \\
\hline & $(0.0894)$ & $(0.0598)$ & $(0.0257)$ & $(0.1307)$ & $(0.0656)$ & \\
\hline \multirow{2}{*}{ Summer } & 0.0760 & 0.0089 & 0.0463 & -0.1676 & -0.1420 & \\
\hline & $(0.1426)$ & $(0.0740)$ & $(0.0374)$ & $(0.1586)$ & $(0.0943)$ & \\
\hline \multirow[t]{2}{*}{ Woman's age } & -0.0138 & -0.0142 & -0.0027 & $0.0281 * *$ & 0.0216 & $* * *$ \\
\hline & $(0.0130)$ & $(0.0082)$ & $(0.0036)$ & $(0.0140)$ & $(0.0080)$ & \\
\hline \multirow[t]{2}{*}{ Woman has a university degree } & -0.1097 & -0.0914 & -0.0395 & 0.2274 & 0.2522 & $*$ \\
\hline & $(0.1854)$ & $(0.1487)$ & $(0.0672)$ & $(0.2440)$ & $(0.1368)$ & \\
\hline \multirow[t]{2}{*}{ Woman is in poor health } & 0.4104 & 0.1592 & -0.0545 & -0.4970 & 0.3007 & \\
\hline & $(0.3496)$ & $(0.2458)$ & $(0.0856)$ & $(0.3149)$ & $(0.2702)$ & \\
\hline
\end{tabular}




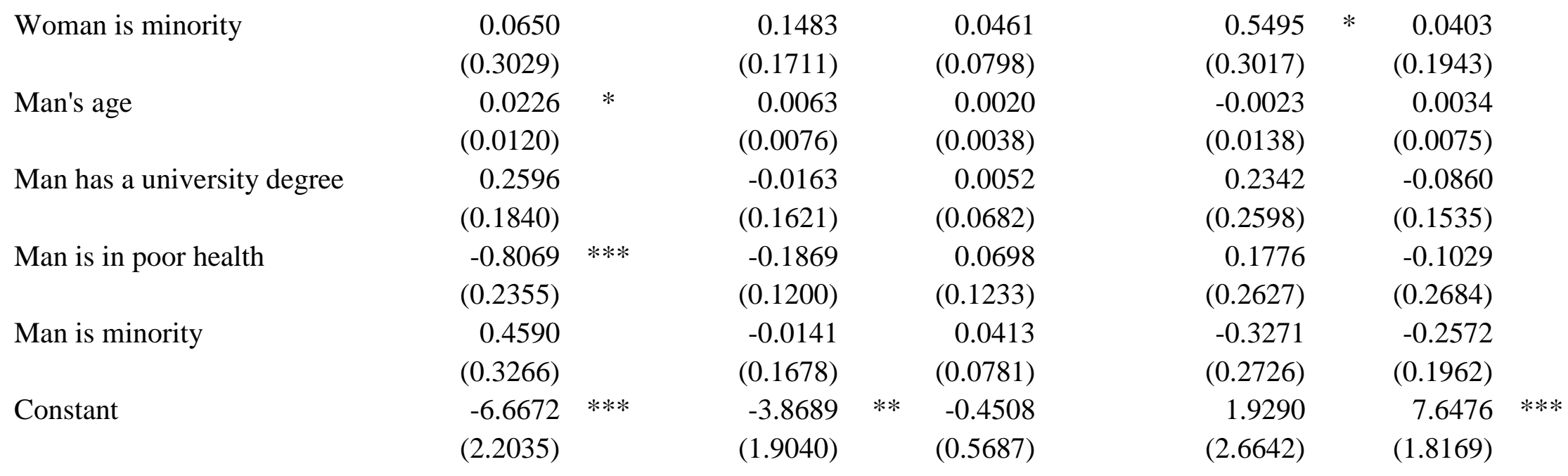

Standard errors in parentheses.

Asterisks indicate significance using a 2-tailed test: *** $1 \%, * * 5 \%, * 10 \%$. 